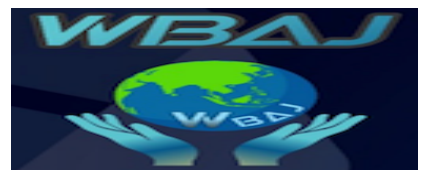

Volume 2 Issue 1, Juni 2020

https://ejournal.unsub.ac.id/index.php/bisnis

\title{
PENGARUH LINGKUNGAN KERJA TERHADAP KINERJA KARYAWAN PADA PT. HADE DINAMIS SEJAHTERA
}

\author{
Vicky Karina ${ }^{1}$
}

Fakultas Ilmu Administrasi Universitas Subang

vicky.karina1203@gmail.com

Silvy Sondari Gadzali²

Fakultas Ilmu Administrasi Universitas Subang

silvysondari.gadzali@gmail.com

\section{Isniar Budiarti ${ }^{3}$}

Fakultas Ekonoomi dan Bisnis Unikom

Isniarbudiarti@gmail.com

\begin{abstract}
Abstrak
Kinerja Karyawan pada PT. Hade Dinamis Sejahtera mengalami kemunduran selama dua tahun terakhir yang diindikasi karena pengaruh Lingkungan Kerja yang kurang memadai. Pengaruh lingkungan kerja terhadap kinerja karyawan, bahwa para karyawan menaruh perhatian yang besar terhadap lingkungan kerja mereka, baik dari segi kenyamanan pribadi maupun kemudahan melakukan pekerjaan dengan baik. Penelitian menggunakan pendekatan kuantitatif. Teknik pengumpulan data menggunakan kuesioner yang disebarkan kepada karyawan PT. Hade Dinamis Sejahtera. Jumlah populasi dalam penelitian ini berjumlah 112 orang, pengambilan sampel yang digunakan oleh peneliti adalah teknik acak sederhana. Analisis data yang digunakan adalah statistik deskriptif dan analisis regresi linier sederhana dengan menggunakan software SPSS 22 untuk membantu perhitungannya. Hasil penelitian ini menunjukan bahwa secara simultan variabel bebas lingkungan kerja $(X)$ berpengaruh signifikan terhadap variabel terikat yaitu kinerja karyawan (Y). Sementara itu, analisis deskriptif menunjukan bahwa dengan lingkungan kerja yang berada pada tingkat kuat, didapatkan kinerja karyawan yang kuat pula.
\end{abstract}

Kata kunci: lingkungan kerja, kinerja karyawan 


\begin{abstract}
The employee performance at PT. Hade Dinamis Sejahtera has been decreasing over the past two years due to an inadequate work environment. Work environment on employee performance, that employees pay great attention to their work environment, both in terms of personal comfort and ease of doing good work. This research user a quantitative approach and data collection techniques using a distributed questionnaire to employees of PT. Hade Dinamis Sejahtera. The population in this study amounted to 112 people, the sampling used in this research was a simple random technique. The data analisys used was descriptive statistics and simple linear regression using SPSS 22 software to help the calculationThe results of this study indicate that simultaneously the independent variable work environment $(X)$ significantly influences the dependent variable employee performance $(Y)$. Meanwhile, descriptive analysis shows that with a strong level work environment is also obtained strong employee performance.
\end{abstract}

Keywords : work environment, employee performance

\title{
Pendahuluan
}

Memasuki era global dunia industri saat ini menunjukkan peningkatan ekonomi yang memberikan prospek yang cerah bagi setiap pihak atau perusahaan yang mampu bersaing dengan perusahaan lainnya dalam industri yang sama baik bisnis barang maupun jasa. Tidak lepas dari itu pihak perusahaan tentu ingin mendapatkan hasil yang maksimal atau dengan kata lain ingin mendapatkan keuntungan dari kegiatan usaha tersebut. Sesuai dengan kondisi tersebut, perusahaan harus mampu menyesuaikan dengan adanya perubahan-perubahan. Dengan adanya perubahan-perubahan secara langsung ataupun tidak langsung akan berpengaruh terhadap kinerja karyawan dan akan mempengeruhi pula terhadap kondisi perusahaan. Pengaruh lingkungan kerja tehadap kinerja atau prestasi kerja karyawan sangat penting bagi sebuah perusahaan baik lingkungan internal maupun lingkungan eksternal karena akan memengaruhi tujuan dari perusahaan (Wibowo, 2007).

Kinerja karyawan yang tinggi sangat diharapkan oleh perusahaan tersebut. Semakin banyak karyawan yang mempunyai kinerja tinggi, maka produktifitas perusahaan secara keseluruhan akan meningkat sehingga perusahaan akan dapat bertahan dalam persaingan global. Dengan kata lain ketergantungan suatu perusahaan ditentukan oleh kinerja karyawannya. Setiap pekerja mempunyai kemampuan mendasar pada pengetahuan dan keterampilan, kompetensi yang sesuai dengan pekerjaannya, motivasi kerja, dan kepuasaan kerja. Namun pekerja mempunyai kepribadian, sikap, dan perilaku yang mempengaruhi kinerja. Kepemimpinan dan gaya kepemimpinan dalam perusahaan sangat berperan dalam mempengaruhi kinerja karyawan. Bagaimana pemimpin menjalin hubungan dengan pekerja, bagaimana mereka memberikan penghargaan kepada pekerja yang berprestasi, bagaimana mereka mengembangkan dan memperdayakan pekerjanya, sangat mempengaruhi kinerja sumber daya manusia yang 
menjadi bawahanya. Karyawan dituntut untuk mampu menyelesaikan tugas dan tanggung jawabnya secara efektif dan efisien. Keberhasilan karyawan dapat diukur melalui kepuasan konsumen, berkurangnya jumlah keluhan dan tercapainya target yang optimal.

Salah satu faktor lain yang mempengaruhi kinerja karyawan adalah faktor lingkungan kerja. Lingkungan kerja adalah komponen-komponen yang merujuk pada lembaga atau kekuatan yang berinteraksi langsung maupun tidak langsung menurut pola tertentu, mengenai organisasi atau perusahaan yang tidak akan bisa lepas dari lingkungan dimana organisasi atau peruasahaan itu berada. Demikian pula apakah lingkungan kerja atau situasi kerja memberikan kenyamanan sehingga mendorong kinerja karyawan (Wibowo, 2014).

PT. Hade Dinamis Sejahtera merupakan salah satu perusahaan di Kabupaten Subang tepatnya di Kecamatan Cipeundeuy Desa Sawangan, yang bergerak pada bidang peternakan yakni sapi. PT. Hade Dinamis Sejahtera di dirikan pada tahun 2005 dan telah memiliki 112 karyawan yang terdiri dari berbagai bidang. Sebagai perusahaan yang terhitung baru perusahaan memikirkan untuk keberlangsungan perusahaan tersebut untuk terus bertahan dan meginginkan kinerja karyawannya selalu meningkat dan target yang ditetapkan selalu tercapai, sehingga manajer mengupayakan agar terwujudnya keinginan tersebut. Tetapi berdasarkan data dan wawancara dilapangan yang diperoleh pada masa penjajagan di PT. HDS tidak tercapainya target penjualan sapi selama 2 tahun terakhir yakni 2017 dan 2018.

Berdasarkan data kinerja karyawan pada PT. HDS pada tahun 2017-2018 diduga terdapat ketidakoptimalan kinerja kerja karyawan. Hal ini disinyalir juga disebabkan karena lingkungan kerja fisik dan non fisik. Dengan demikian dapat dipaparkan indikator permasalahan kinerja karyawan sebagai berikut :

1. Kualitas hasil kerja karyawan masih terdapat kesalahan dalam pengerjaannya, seperti laporan bulanan yang dibukukan secara manual. Hasil wawancara dengan manajer rata-rata pendidikan karyawan yaitu tamat SLTP/SMP.

2. Kuantitas hasil kerja karyawan masih dibawah target perusahaan.

Sebagai perusahaan yang bergerak dibidang peternakan lingkungan kerja bisa menjadi salah satu faktor baik tidaknya kinerja karyawan

\section{Kerangka Teori}

Manajemen Sumber Daya Manusia

Manajemen Sumber Daya Manusia adalah ilmu dan seni mengatur hubungan dan peranan tenaga kerja agar efektif dan efisien membantu terwujudnya tujuan perusahaan, karyawan dan masyarakat (Hasibuan, 2007:10). Sependapat dengan John B.Miner dan Mary Green Miner dalam (Hasibuan, 2007:11) menyatakan bahwa Manajemen Personalia didefinisikan sebagai suatu proses pengembangan, menerapkan, dan menilai kebijakankebijakan, prosedur-prosedur, metode-metode, dan program-program yang berhubungan dengan individu karyawan dalam organisasi. 


\section{Lingkungan Kerja}

Lingkungan kerja dalam suatu perusahaan sangat penting untuk diperhatikan manajemen. Meskipun lingkungan kerja tidak melaksanakan proses produksi dalam suatu perusahaan,namun lingkungan kerja mempunyai pengaruh langsung terhadap para karyawan yang melaksanakan proses produksi tersebut. Lingkungan kerja adalah suasana dimana karyawan melakukan aktivitas setiapharinya. Lingkungan kerja yang kondusif memberikan rasa aman dan memungkinkan karyawan untuk dapat bekerja optimal.

Hal ini dikemukakan oleh Nitisemito dalam Nuraini (2013:97) bahwa lingkungan kerja merupakan semua yang ada pada pekerja dan dapat mempemgaruhi dalam menjalankan pekerjaan yang telah diembankan. Senada yang diungkapkan oleh Sedarmayati (2009:21) “Lingkungan kerja adalah keseluruhan alat perkakas dan bahan yang dihadapi, lingkungan sekitarnya dimana sesorang bekerja, metode kerjanya, serta pengaturan kerjanya baik sebagai perseorangan maupun kelompok".

Sedangkan menurut Lewa dan Subono (2005:235) bahwa "Lingkungan kerja didesain sedemikian rupa agar dapat tercipta hubungan kerja yang mengikat pekerja dengan lingkungan. Lingkungan kerja yang menyenangkan dapat membuat para karyawan merasa betah dalam menyelesaikan pekerjaannya serta mampu mencapai suatu hasil yang optimal. Sebaliknya apabila kondisi lingkungan kerja tersebut tidak memadai akan menimbulkan dampak negatif dalam penurunan tingkat produktifitas kinerja karyawan".

Jenis lingkungan kerja terbagi menjadi dua faktor yaitu faktor lingkungan kerja fisik dan faktor lingkungan kerja non fisik (Sedarmayanti, 2011) :

1. Faktor Lingkungan Kerja Fisik

a Warna merupakan faktor yang penting untuk memperbesar efisiensi kerja para pegawai. Khususnya warna akan mempengaruhi keadaan jiwa mereka. Dengan memakai warna yang tepat pada dinding ruangan dan alat-alat lainnya, kegembiraan dan ketenangan bekerja para pegawai akan terpelihara.

b Kebersihan lingkungan kerja secara tidak langsung dapat mempengaruhi seseorang dalam bekerja, karena apabila lingkungan kerja bersih maka karyawan akan merasa nyaman dalam melakukan pekerjaannya. Kebersihan lingkungan bukan hanya berarti kebersihan tempat mereka bekerja, tetapi jauh lebih luas dari pada itu misalnya kamar kecil yang berbau tidak enak akan menimbulkan rasa yang kurang menyenangkan bagi para karyawan yang menggunakannya, untuk menjaga kebersihan ini pada umumnya diperlukan petugas khusus, dimana masalah biaya juga harus dipertimbangkan disini.

c Penerangan dalam hal ini bukan terbatas pada penerangan listrik saja, tetapi juga penerangan sinar matahari. Dalam melaksanakan tugas karyawan membutuhkan penerangan yang cukup, apabila pekerjaan yang dilakukan tersebut menuntut ketelitian. 
d Pertukaran udara yang cukup akan meningkatkan kesegaran fisik para karyawan, karena apabila ventilasinya cukup maka kesehatan para karyawan akan terjamin. Selain ventilasi, konstrusi gedung dapat berpengaruh pula pada pertukaran udara. Misalnya gedung yang mempunyai plafond tinggi akan menimbulkan pertukaran udara yang banyak dari pada gedung yang mempunyai plafond rendah selain itu luas ruangan apabila dibandingkan dengan jumlah karyawan yang bekerja akan mempengaruhi pula pertukan udara yang ada.

e Jaminan terhadap keamanan menimbulkan ketenangan. Keamanan akan keselamatan diri sendiri sering ditafsirkan terbatas pada keselamatan kerja, padahal lebih luas dari itu termasuk disini keamanan milik pribadi karyawan dan juga konstruksi gedung tempat mereka bekerja. Sehingga akan menimbulkan ketenangan yang akan mendorong karyawan dalam bekerja.

f Kebisingan merupakan suatu gangguan terhadap seseorang karena adanya kebisingan, maka konsentrasi dalam bekerja akan terganggu. Dengan terganggunya konsentrasi ini maka pekerjaan yang dilakukan akan banyak menimbulkan kesalahan atau kerusakan. Hal ini jelas akan menimbulkan kerugian. Kebisingan yang terus menerus mungkin akan menimbulkan kebosanan.

g Tata ruang merupakan penataan yang ada di dalam ruang kerja yang biasa mempengaruhi kenyamanan karyawan dalam bekerja.

2. Faktor Lingkungan Kerja Non Fisik

a Struktur Kerja, pekerjaan yang diberikan memiliki struktur kerja dan organisasi yang baik.

b Tanggung jawab kerja, karyawan mengerti tanggung jawab serta bertanggung jawab atas tindakan yang dilakukan.

c Perhatian dan dukungan pemimpin, karyawan merasakan bahwa pimpinan sering memberikan pengarahan, keyakinan, perhatian serta menghargai hasill kerja yang dilakukan.

d Kerja sama antar kelompok, karyawan merasakan ada kerjasama yang baik diantara kelompok kerja yang ada.

e Kelancaran komunikasi, karyawan merasakan adanya komunikasi yang baik, terbuka dan lancer, baik antara teman sekerja ataupun dengan pimpinan.

Sementara Simanjuntak (2003:39) Lingkungan kerja dapat dibagi menjadi beberapa bagian atau bisa disebut juga aspek pembentuk lingkungan kerja, bagian-bagian itu bisa diuraikan sebagai berikut:

1. Pelayanan kerja

Pelayanan karyawan merupakan aspek terpenting yang harus dilakukan oleh setiap perusahaan terhadap tenaga kerja. Pelayanan yang baik dari perusahaan akan membuat karyawan lebih bergairah dalam bekerja, mempunyai rasa tanggung jawab dalam menyelesaikan pekerjaannnya, serta dapat terus mennjaga 
nama baik perusahaan melalui produktivitas kerjanya dan tingkah lakuknya. Pada umumnya pelayanan karyawan meliputi beberapa haln yakni :

a Pelayanan makan dan minum.

b Pelayanan kesehatan

c Pelayanan kamar kecil/kamar mandi ditempat kerja, dan sebagainya.

2. Kondisi Kerja

Kondisi kerja karyawan sebaiknya diusahakan oleh manajemen perusahaan sebaik mungkin agar timbul rasa aman dalam bekerja untuk karyawannya, kondisi kerja ini meliputi penerangan yang cukup, suhu udara yang tepat, kebisingan yang ddapat dikendalikan, pengaruh warna, runag gerak yang diperlukan dan keamanan kerja karyawan.

3. Hubungan Karyawan

Hubungan karyawan akan sangat menentukan dalam menghasilkan kepuasan kerja. Hal ini disebabkan karena adanya hubungan antara motivasi serta semangat dan kegairahan kerja dengan hubungan yang kondusif antar sesame karyawan dalam bekerja, ketidak serasian hubungan antara karyawan dapat menurunkan motivasi dan kegairahan yang akibatnya akan dapat menurunkan kepuasan kerja.

\section{Kinerja Karyawan}

Rivai \& Basri, 2004; Harsuko (2011) “Kinerja apabila dikaitkan dengan performance sebagai kata benda (noun), maka pengertian performance atau hasuka kinerja adalah hasil kerja yang dapat dicapai oleh seseorang atau kelompok orang dalam suatu perusahaan sesuai dengan wewenang dan tanggung jawab masing-masing dalam upaya pencapaian tujuan perusahaan secara ilegal, tidak melanggar hukum dan tidak bertentangan dengan moral dan etika". Hal senada dikemukakan oleh Mangkunegara (2004:67) bahwa kinerja (performance) adalah hasil kerja secara kualitas dan kuantitas yang dicapai oleh seseorang karyawan dalam melaksanakan tugasnya sesuai dengan tanggungjawab yang diberikan kepadanya.

\section{Faktor-faktor Kinerja Karyawan}

Ruky (2000:21) ada lima faktor yang dapat mempengaruhi kinerja karyawan yaitu :

1. Fasilitas Kantor, adalah merupakan sarana yang dapat menunjang seorang karyawan untuk melakukan aktivitas kerjanya dengan baik, dan apabila organisasi tidak dapat memberikan fasilitas kerja yang memaai maka dapat berdampak pada penurunan kinerja karyawan. Sebab seorang karyawan tentu membutuhkan sarana kerja yang sangat berkualitas untuk dapat menunjang kerjanya dalam upaya mencapai tujuan organisasi yang telah ditentukan.

2. Lingkungan Kerja, adalah merupakan faktor penting dalam organisasi, karena hamper $80 \%$ karyawan akan merasa tidak nyaman dalam bekerja jika lingkungan kerja tidak baik. Lingkungan kerja yang baik memiliki ruang kerja yang cukup 
luas, penerangan (lampu) yang sempurna dan temperature udara yang sesuai dengan luar ruangan yang dimiliki.

3. Prioritas kerja, yakni pemberian prioritas kerja yang jelas dan bertanggungjawab, sebab jika tidak maka karyawan akan bekerja seakan tanpa arah yang jelas. Prioritas kerja merupakan tahapan penting bagi karyawan dalam menentukan skala prioritas perkerjaan organisasi. Prioritas kerja juga sangat memperhatikan aspek waktu dan tanggungjawab bagi karyawan yang melaksanakan tugas organisasi.

4. Supportive boss, adalah lebih menekankan pentingnya posisi atasan ketika karyawan sedang melaksanakan tugas-tugas organisasi. Sebagai pimpinan maka tugas yang paling penting adalah memberikan dukungan kepada karyawan untuk mengemukakan pendapat dan ide-ide baru pada pada saat rapat atau pertemuan rutin. Sebagai pimpinan yang demokratis tentu akan melibatkan karyawan pada saat ada kesempatan diskusi umtuk memecahkan suatu masalah atau mencari solusi terbaik dalam memecahkan masalah yang sedang dihadapi organisasi.

5. Bonus, adalah bentuk penghargaan yang paling realistis terhadap karyawan yang dapat menyelesaikan tugas dengan baik dan sesuai dengan waktu yang telah ditentukan. Penghargaan itu bentuknya tidak harus bersifat kebendaan tetapi dapat pula dalam bentuk lain seperti yang paling sederhana adalah ucapan terima kasih dan pujian didepan karyawan yang lain, tujuannya adalah untuk memicu karyawan lain melakukan hal yang sama. Tetapi bonus materi memang sangat berpengaruh terhadap kinerja karyawan.

Timpe (2004:9) berpendapat yakni kinerja seseorang dapat dipengaruhi oleh faktor internal dan faktor eksternal, yaitu :

1. Faktor Internal

Faktor internal adalah faktor yang berasal dari dalam atau karyawan itu sendiri, seperti sikap, prilaku dan kemampuan pekerja sosial fungsional dapat mempengaruhi kerja sehari-hari

2. Faktor Eksternal

Faktor eksternal adalah faktor yang berasal dari lingkungan karyawan. Faktor ini dapat mempengaruhi kacakapan dan motivasi pekerja sosial fungsional. Faktor ekternal yang menentukan tingkat kinerja karyawan adalah lingkungan, perilaku manajemen, desain jabatan, penilaian kerja, umpan balik dan administrasi pengupahan.

\section{Penilaian Kinerja}

Penilaian kinerja merupakan usaha yang dilakukan pimpinan untuk menilai hasil kerja bawahannya. Penilaian kinerja adalah suatu sistem yang digunakan untuk menilai dan mengetahui apakah seorang karyawan telah melaksanakan pekerjaannya dalam suatu organisasi melalui instrument penilaian kinerja. Pada hakikatnya, penilaian kinerja 
merupakan suatu evaluasi terhadap penampilan kerja individu dengan membandingkan standar baku penampilan.

Penilaian karyawan merupakan evaluasi yang sistematis dari pekerjaan karyawan dan potensi yag dapat dikembangkan. Penilaian dalam proses penafsiran atau penentuan nilai, kualitas atau status dari beberapa obyek orang ataupun sesuatu barang (Mangkunegara, 2005:10). Sejalan dengan pendapat Handoko (2005:235) bahwa penilaian prestasi kerja (performance appraisal) adalah proses melalui mana organisasiorganisasi mengevaluasi atau menilaiprestasi kerja karyawan.

\section{Aspek-Aspek Penilaian Kinerja}

Menurut Rivai (2005:324), aspek-aspek yang dinilai dalam penilaian kinerja meliputi sebagai berikut:

1. Kemampuan teknis, yaitu kemampuan menggunakan pengetahuan, metode, teknik dan peralatan yang dipergunakan untuk melaksanakan tugas serta pengalaman serta pelatihan yang diperoleh.

2. Kemampuan konseptual, yaitu kemampuan untuk memahami kompleksitas perusahaan dan menyesuaian bidang gerak dari unit masing-masing ke dalam bidang operasional perusahaan serta menyeluruh, yang pada intinya individual tersebut memahami tugas, fungsi serta tanggung jawabnya sebagai seorang karyawan.

3. Kemampuan hubugan interpersonal, yaitu antara lain umtuk bekerja sama dengan orang lain, memotivasi karyawan, melakukan negosiasi dan sebagainya.

\section{Indikator Kinerja Karyawan}

Menurut Robbins (2002) indikator kinerja karyawan diuraikan sebagai berikut:

1. Kuantitas Hasil Kerja

Merupakan jumlah produksi kegiatan yang dihasilkan atau diselesaikan. Pengukuran kuantitatif melibatkan perhitungan keluaran dari proses atau pelaksanaan kegiatan ini berkaitan dengan jumlah keluaran yang dihasilkan. Kuantitas hasil kerja dapat dilihat dari prestasi kerja yang dicapai karyawan dan pencapaian target pekerjaan karyawan.

2. Kualitas Hasil Kerja

Merupakan mutu yang harus dihasilkan (baik tidaknya). Pengukuran kualitatif keluaran mencerminkan pengukur "tingkat kepuasan", yaitu seberapa baik penyelesaiannya. Ini berkaitan dengan bentuk keluaran seperti keterampilan, kepuasan pelanggan, ataupun inisiatif.

3. Ketepatan Waktu

Merupakan sesuai tidaknya dengan waktu yang direncanakan. Pengukuran ketepatan waktu merupakan jenis khusus dari pengukuran kuantitatif yang menentukan ketepatan waktu penyelesaian suatu kegiatan. Hal ini dapat kita lihat dari tingkat kehadiran karywan, ketaatan karyawan dalam bekerja. 


\section{Pengaruh Lingkungan Kerja Terhadap Kinerja Karyawan}

Robbins (2002) mengemukakan adanya pengaruh lingkungan kerja terhadap kinerja karyawan "bahwa para karyawan menaruh perhatian yang besar terhadap lingkungan kerja mereka, baik dari segi kenyamanan pribadi maupun kemudahan melakukan pekerjaan dengan baik. Lingkungan kerja dapat dibedakan menjadi dua yaitu lingkungan kerja fisik dan non fisik. Terciptanya lingkungan kerja yang baik dapat dapat berpengaruh terhadap kinerja karyawan. Lingkungan kerja fisik dan non fisik juga berpengaruh terhadap motivasi dan semangat kerja karyawan karena apabila lingkungan kerja di perusahaan tersebut nyaman dan menyenangkan tentunya karyawan dapat meningkatkan kinerjanya sehingga tujuan perusahaan dapat tercapai dengan baik.

\section{Metode Penelitian}

Metode yang digunakan dalam penelitian adalah metode kuantitatif karena metode penelitian ini berlandaskan pada filsafat positifisme (filsafat positifisme mamandang realitas, gejala, fenomena itu dapat diklarifikasikan, relative tetap, kongkrit, teramati, terukur, dan hubungan realistis, gejala, fenomena bersifat sebab dan akibat), digunakan untuk meneliti pada populasi atau sampel tertentu, pengumpulan data menggunakan instrumen penelitian, analisis data bersifat kuantitatif/statistic, dengan tujuan untuk menguji hipotesis yang telah ditetapkan (Sugiono, 2016). Metode ini dipakai untuk menguji teori yang digunakan, melihat perbandingan, mengetahui hubungan, melakukan pengelompokan maupun penyederhanaan variabel sehigga diharapkan dapat menjelaskan pengaruh lingkungan kerja terhadap kinerja karyawan.

\section{Populasi dan Sampel}

Populasi dalam penelitian berjumlah 112 orang. Dimana penentuan sampel menggunakan teknik acak sederhana (simple random sampling). Dikatakan simple (sederhana) karena pengambian anggota sampel dari populasi dilakukan secara acak tanpa memperhatikan strata yang ada dalam populasi. Dari data yang diperoleh diatas, populasi yang akan diteliti sebanyak 112 orang, dengan tingkat kesalahan 5\%.

\section{Instrumen Penelitian}

Instrumen yang digunakan dalam penelitian ini berbentuk angket atau kuesioner, dengan jumlah variabel sebanyak 2 variabel dan menggunakan skala likert dalam pengukuran jawaban dari para responden. Dengan skala likert, maka variabel yang akan diukur akan dijabarkan menjadi indikator variabel. Kemudian indikator tersebut dijadikan tolak ukur untuk menyusun item-item instrument dalam bentuk pertanyaan. Jawaban dari setiap responden memiliki tingkatan nilai dari sangat positif sampai sangat negatif.

Proses pengumpulan data yang diperlukan dalam pembahasan ini melalui dua tahap penelitian, yaitu:

\section{Studi Kepustakaan (Library Research)}


Studi kepustakaan digunakan untuk mengumpulkan data sekunder dari perusahaan, landasan teori dan informasi yang berkaitan dengan penelitian ini dengan cara dokumentasi.

2. Studi Lapangan (Field Research)

Teknik pengumpulan data yang dipergunakan adalah sebagai berikut :

a. Observasi

b. Angket

\section{Hasil dan Pembahasan \\ Pelayanan Kerja}

Hasil penelitian menyatakan bahwa Tingginya respon baik responden terhadap pelayanan yang diberikan oleh perusahaan sehingga berdampak baik pada kinerja karyawan. Pelayanan kerja bagi karyawan adalah suatu usaha yang dilakukan oleh pihak perusahaan dan diperuntukan kepada karyawan berupa tindakan pelayanan umum penjamin hidup dan perlindungan serta pemberian bantuan kepada keryawan demi peningkatan kesejahteraan para karyawan. (Siagian, 2002)

\section{Kondisi Kerja}

Hasil jawaban responden, terdapat enam pernyataan yang berhubungan dengan indikator Kondisi Kerja, dengan hasil jawaban terbanyak mengenai pernyataan terdapat jaminan keamanan kerja karyawan saat berada ditempat kerja. Oleh karena itu, agar karyawan melakukan tugasnya dengan optimal, tentu yang harus diperhatikan adalah kondisi kerja. Tersedianya kondisi kerja yang memadai tentu sangat menunjang kinerja karyawan. Ketika kondisi kerja tidak memadai, kemungkinan karyawan perlu mencari kondisi kerja demi menyelesaikan tugasnya. Dari hasil keseluruhan jawaban responden banyaknya responden menjawab setuju atas kondisi kerja yang diberikan perusahaan ini berdampak baik pada kinerja karyawan.

\section{Hubungan Karyawan}

Hubungan karyawan yang terjalin baik dan harmonis dapat meningkatkan semangat dan kinerja karyawan. Hubungan karyawan dalam organisasi merupakan kebutuhan sosial yang menekankan interaksi antar individu dalam organisasi. Interaksi antara sesame karyawan atau bawahan dengan pimpinan diharapkan dapat menjalin interaksi untuk saling menghormati dan menunjukan adanya kebersamaan. Menurut Rivai (2004) menyatakan bahwa rasa puas atau tidak puas terhadap pekerjaan ditinjau dari segi sosial psikologi adalah berhubungan dengan pergaulan antara karyawan dengan karyawan dan antara karyawan dengan atasannya.

\section{Analisis Rekapitulasi Skor Variabel Lingkungan Kerja}

Hasil rekapitulasi skor variabel Lingkungan Kerja diatas dapat dijelaskan bahwa besarnya persentase yang menyatakan setuju menunjukan para karyawan 
membutuhkan Lingkungan Kerja yang memadai dalam rangka menyelesaikan tugas pekerjaannya, dengan memberikan Lingkungan Kerja yang baik kepada karyawan seperti pelayanan karyawan yang baik, kondisi kerja yang membuat karyawan merasa nyaman juga hubungan karyawan dengan karyawan atau dengan atasan terjalin baik membuat para karyawan dapat berkerja dengan baik dan merasa nyaman dengan semua tugas yang diembannya. Setelah karyawan merasa nyaman dengan pekerjaannya, para karyawan akan saling menghargai hak dan kewajiban sesama karyawan sehingga terciptalah suasana kerja yang kondusif, pada akhirnya karyawan dengan bersungguhsungguh memberikan kemampuan terbaiknya dalam menjalankan tugas dan tanggung jawabnya, dan ini berarti proses pencapaian tujuan perusahaan akan segera tercapai.

\section{Kinerja Karyawan}

\section{Kuantitas Hasil Kerja}

Kuantitas hasil kerja merupakan salah satu indikator menentukan tinggi rendahnya kinerja karyawan. Pada perusahaan ini dapat dilihat dari jawaban responden banyak yang setuju akan pentingnya menargetkan pekerjaan mereka setiap harinya. Namun ada juga yang yang masih ragu-ragu untuk membuat target kerja setiap hari.

\section{Kualitas Hasil Kerja}

Kuanlitas hasil kerja merupakan salah satu indikator menentukan tinggi rendahnya kinerja karyawan. Pada perusahaan ini dapat dilihat dari jawaban responden banyak yang setuju akan pentingnya ketelitian dalam bekerja juga bekerja sesuai dengan petunjuk yang diberikan sehingga minimnya terjadi kesalahan, dan bertanggungjawab atas pekerjaan yang telah dikerjakan

\section{Ketepatan Waktu}

Ketepatan waktu dalam kerja merupakan salah satu indikator menentukan tinggi rendahnya kinerja karyawan. Pada perusahaan ini dapat dilihat dari jawaban responden banyak yang setuju akan pentingnya ketepatan waktu dalam menyelesaikan pekerjaan dan sadar akan pentingnya disiplin waktu merupakan kewajiban setiap karyawan.

\section{Analisis Rekapitulasi Skor Variabel Kinerja Karyawan}

Hasil skor keseluruhan variabel kinerja karyawan dapat dijelaskan bahwa besarnya persentase kinerja karyawan menyatakan setuju, karena para karyawan selalu terus berorientasi untuk memberikan kuantitas dan Kualitas Hasil Kerja yang maksimal dan karyawan telah melaksanakan pekerjaanya dengan tepat waktu dan terarah sesuai dengan harapan serta tujuan yang ingin dicapai oleh perusahaan.

\section{Pengaruh Lingkungan Kerja Terhadap Kinerja Karyawan}

Menurut Robbins (2002) mengemukakan adanya pengaruh lingkungan kerja terhadap kinerja karyawan "bahwa para karyawan menaruh perhatian yang besar terhadap lingkungan kerja mereka, baik dari segi kenyamanan pribadi maupun 
kemudahan melakukan pekerjaan dengan baik. Lingkungan kerja dapat dibedakan menjadi dua yaitu lingkungan kerja fisik dan non fisik. Terciptanya lingkungan kerja yang baik dapat dapat berpengaruh terhadap kinerja karyawan. Lingkungan kerja fisik dan non fisik juga berpengaruh terhadap motivasi dan semangat kerja karyawan karena apabila lingkungan kerja di perusahaan tersebut nyaman dan menyenangkan tentunya karyawan dapat meningkatkan kinerjanya sehingga tujuan perusahaan dapat tercapai dengan baik."

Dijelaskan pula hasil penelitian bahwa dapat diperoleh gambaran pengaruh lingkungan kerja terhadap kinerja karyawan telah sesuai dengan yang dikemukakan oleh Robbins (2002). Lingkungan kerja yang diukur dengan tiga indikator yaitu pelayanan kerja, kondisi kerja dan hubungan karyawan berpengaruh terhadap kinerja karyawan yang diukur dengan tiga indikator yaitu Kuantitas Hasil Kerja, Kualitas Hasil Kerja dan ketepatan waktu. Pada penelitin ini diperoleh hasil bahwa terdapat pengaruh yang sedang antara lingkungan kerja terhadap kinerja karyawan pada PT. Hade Dinamis Sejahtera Berdasarkan hasil perhitungan SPSS 22 menunjukan bahwa adanya hubungan yang cukup kuat antara variabel lingkungan kerja $(X)$ terhadap variabel kinerja karyawan $(Y)$ dengan hasil perhitungan $r_{h i t u n g}$ lebih besar dari $r_{\text {tabel }}$ yakni 0,643 > 0,209 maka Ho ditolak Ha diterima.

Selain diperkuat dari uji koefisien korelasi, korelasi antara variabel $\mathrm{X}$ dan variabel Y diuji dengan Uji regresi (Parameter $\beta$ ) secara pasrial (uji t), dengan hasil thitung lebih besar dari tabel yaitu 5,621 >1,662. Oleh karena itu, terdapat hubungan yang cukup kuat dan signifikan antara lingkungan kerja terhadap kinerja karyawan pada PT. Hade Dinamis Sejahtera. Dengan kata lain, lingkungan kerja tidak diperhatikan maka kinerja karyawan kurang sesuai dengan yang diharapkan. Sebaliknya apabila lingkungan kerja sangat diperhatikan maka kinerja karyawan akan berjalan dengan baik sesuai dengan harapan.

Selanjutnya untuk menghitung seberapa besar pengaruh variabel lingkungan kerja $(X)$ terhadap Variabel kinerja karyawan $(Y)$, berdasarkan hasil hitung uji koefisien determinasi menunjukan bahwa $\mathrm{R}$ square sebesar 0,269 atau $0,269 \times 100 \%=26,9 \%$ yang berarti bahwa variabel independen (Lingkungan Kerja) mempengaruhi variabel dependen (Kinerja Karyawan) sebesar 26,9\% dan sisanya sebesar 73,1\% yang diperkirakan dipengaruhi oleh faktor lain seperti faktor kemampuan dan keahlian, pengetahuan, rancangan kerja, kepribadian, motivasi kerja, kepemimpinan, budaya organisasi, kepuasan kerja, loyalitas, komitmen, dan disiplin kerj yang dikemukakan oleh Kasmir (2016:65-71). Namun, faktor tersebut tidak diteliti lebih lanjut oleh peneliti melainkan dapat diteliti oleh peneliti lain sebagai acuan untuk diteliti dan dikembangkan lagi.

\section{Kesimpulan}

Dari hasil analisis data dan informasi yang diperoleh serta didukung oleh hasil angket, dapat disimpulkan sebagai berikut: 
1. Lingkungan kerja pada PT. Hade Dinamis Sejahtera, berdasarkan hasil jawaban responden yaitu sangat setuju, setuju dan ragu-ragu, namun tanggapan lebih dominan yang menjawab setuju. Hasil dari penelitian Indikator yang menunjukan baiknya lingkungan kerja di perusahaan ini adalah pelayaan kerja dan hubungan karyawan namun kondisi masih kurang diperhatikan.

2. Kinerja karyawan pada PT. Hade Dinamis Sejahtera, berdasarkan hasil jawaban responden yaitu sangat setuju, setuju dan ragu-ragu, namun tanggapan lebih dominan yang menjawab setuju. Hasil dari penelitia indikator yang menunjukan kinerja yang tinggi pada perusahaan ini adalah kualitas hasil kerja dan ketepatan waktu kerja namun kuantitas hasil kerja masih kurang.

3. Berdasarkan koefisien determinasi menunjukan, bahwa terdapat pengaruh lingkungan kerja terhadap kinerja karyawan sebesar 26,9\% dan sisanya sebesar 73,1\% diperkirakan dipengaruhi oleh faktor lain, namun faktor tersebut tidak diteliti lebih lanjut oleh peneliti melainkan dapat diteliti oleh peneliti lain sebagai acuan untuk diteliti lebih lanjut lagi.

\section{Referensi}

Ahmad S Ruky. 2002. SRobbins, P. Stephen. 2002. Prinsip-Prinsip Perilaku Organisasi. Edisi Kelima.

Aslihah. 2012. Pengaruh Stres Kerja terhadap kinerja karyawan di Koperasi Syari'ah Binama semarang: Universitas Islam Negeri Walisongo Semarang

Burhan. 2005. Metodologi Penelitian Kuantitatif.Jakarta:kencana prenada Media Grup

Filanisa, Ira .2017. pengaruh stres kerja dan jam kerja shifting terhadap kinerja karyawan PT. Infomedia Sokusi Humanika Bandung: Universitas Widyatama

Indasari, Meithiana.2017.Kepuasaan dan Kinerja Karyawan.Sidoarjo:Indo Mediapusaka

Jayanti Rika \& Maulidina.2015.Jurnal. Pengaruh stres kerja terhadap kinerja Pegawai Pada PDAM Titranasi Cabang SEI Agul Medan. Vol 04, No 01,2015-62

Komarudin.2018.Jurnal. Hubungan stres kerja dengan Kinerja Pegawai Pada PT Herona Express kantor pusat Pamulang: Vol.6,No 1,Januari 2018-73

Mu'ah,Masram.2017. Manajemen Sumber Daya Manusia Profesional, Sidoarjo : Zifatama Publisher

Mangkunegara Anwar prabu, 2014. Evaluasi kinerja SDM, Bandung : PT Refika Aditama Marjuni sukmawati,2015.Manajemen Sumber daya manusia, Makassar :CV.Sah Media

Priyonto,2014. Konsep Manajemen Stres, Yogyakarta: Nuha medika

Riandy. 2016. Pengaruh stres kerja terhadap kinerja karyawan Pada PT 


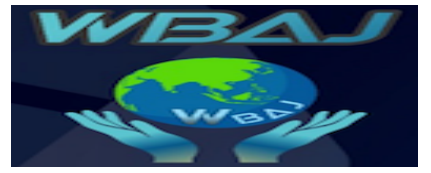

Volume 2 Issue 1, Juni 2020

https://ejournal.unsub.ac.id/index.php/bisnis

Rivai, Veithzal. 2005. Manajemen Sumber Daya Manusia Untuk Perusahaan, Dari Teori Ke Praktek. PT. Rajagrafindo Persada: Jakarta.

Siagian, S. P. 2002. Kiat Meningkatkan Produktivitas Kerja. Jakarta: Rineka cipta.

Timpe, 2004. " Dasar-Dasar Pemasaran dan Sumber Daya Manusia”. Jakarta.

Wibowo. 2007. Manajemen Kinerja. Edisi Kedua. Penerbit PT. Raja Grafindo. Persada. Jakarta.

Wibowo . (2014) . Manajemen Kinerja . Edisi Keempat . Jakarta : Rajawali Pers. 